Article

\title{
Moderate Southeast Asian Islamic Education as a Parent Culture in Deradicalization: Urgencies, Strategies, and Challenges
}

\author{
Sulistiyono Susilo ${ }^{1, *(1)}$ and Reza Pahlevi Dalimunthe ${ }^{2}$ \\ 1 Institute of Social Sciences and Cultural Studies, Yogyakarta 55231, Indonesia \\ 2 Faculty of Islamic Theology, Sunan Gunung Djati State Islamic University, Bandung 40614, Indonesia; \\ rpdalimunthe.uinsgd@gmail.com \\ * Correspondence: sulistiyonosusilo@gmail.com
}

Received: 17 December 2018; Accepted: 7 January 2019; Published: 10 January 2019

check for updates

\begin{abstract}
Radicalization is a terminological conflation of the two meanings in the context of extreme beliefs or behaviors adopted by individuals or groups as a justification for the use of violence to achieve the objectives. Since radicalization primarily emphasises on, and departures from, the understanding and cognitive processes, the role of peaceful and moderate education in this case can be effectively utilized to serve as a considerably relevant means to prevent it. In addition, radicalization is also limited by the social, political, and economic contexts of a particular region, and combined with the degree of individual autonomy in the search for identity. Accordingly, the deradicalization efforts actually necessitate the consideration of the sociopolitical culture as the basis for policy makers. It is based on the consideration that the radicalization of Islam, even though strongly characterized by transnational movement, contains local elements leading to the radicalization as occasionally random and ununiformed violence in the Muslim world. The findings suggest some valuable strategies to deconstruct the idea of radicalization that can be implemented in several ways, including building and empowering local characterization of Indonesian education of Muslims in particular and of Southeast Asian in general, and reducing the Wahhabism extreme teachings and such highly irrational and ahistorical Arabization ideas and programs in Indonesian context.
\end{abstract}

Keywords: deradicalization; moderate education; parent culture; contextualization; Southeast Asia

\section{Introduction}

Terror threats and attacks by extremists in different parts of the world are very serious. Recent trends show a clear increase in the understanding of terrorism and violence associated with Islam, such as the emergence of the Islamic State in Iraq and Syria (ISIS), Boko Haram in Nigeria, As-Shabab in Somalia, the Taliban in Pakistan and Afghanistan and Al Qaeda and its global networks (Berger 2014). Just recently, in early May 2018 several major cities in Indonesia suffered from simultaneous acts of terrorism, starting from the terrorist rebel action at the Brimob Command Headquarter in Depok, the bomb targeting the churches in Surabaya, the attack on Riau Provincial Police Headquarters, and several incidents in the fairly systematic, spontaneous but sporadic sequence. This reinforces the formation and focus of the radical group's strength in Southeast Asia (henceforth commonly cited as ASEAN), an irony regarding its strong perception as a peaceful and multicultural region, and has no historical memory of terror associated with Islam since its very early arrival on the Pacific Rim. Prior to the arrival of this new form of terror, the configuration of resistance of the Islamic-based struggle groups in Southeast Asia, albeit geographically scattered, basically has a clearly identified characterization. The Free Aceh Movement (Gerakan Aceh Merdeka/GAM), the South Thai People's 
Resistance, and Bangsamoro Movement in Mindanao, are politically identified as 'rebellions' which are open and armed struggle targeting the central government's sense of injustice towards Muslims (Tan 2000; Kadir bin Che Man 1987; Tagliacozzo 2009). They declared that their struggle is in search for regional independence, or not affiliated with the global terror groups. This form of rebellion also occurs in areas that are assumed to be controlled by groups who consider themselves minorities, alienated, and marginalized, both in forms of religious, cultural hegemony and historical narratives, as well as economic equality and control over natural resources, which in this context, even GAM group in Aceh situated in a predominantly Muslim country, is also inseparable from this identification. Thus, the process of persuasion or counter-resistance by the central government is usually conducted openly and measurably only in a geographical region with a specific target. This region has only a memory of resistance to the Western colonial (Hadler 2008), until suddenly, albeit still justifiable and contextual, such affiliates of the Taliban, Al Qaeda, and even recently ISIS in Marawi in the Philippines, dominated Islamic terror news from ASEAN (Vaughn et al. 2005). Moreover, the involvement of some groups, like women and children in acts of terror should be of particular concern. It should be remembered that women have been long involved in religious radicalism and terror-based violence, in which they make up about a third of extremists (Roy 1996; see also, Roy 2007). This confirms that acts of terror are not solely due to external influences, but also to the existence of a basic internal process within personal psychology, i.e., the tendency to receive influence for being educated or uneducated matters related to radicalization. Education, henceforth, is the basic word for explaining how initiation of radicalization begins, and can strongly influence vulnerable groups like women, children, and the young (Niemi et al. 2018; Rokhmad and Susilo 2017). Nowadays, the millennials considered a group open to the latest technological developments and massive information that are also often involved in, and withstand to, this action, can be a relevant focus for deradicalization efforts (Roy 2008).

It is necessary to give a brief overview of typical Southeast Asian Islamic education and the problems it faces in connection with the growth of Islamic political activism through jihad by Salafi-Wahhabi institutions, which justifies the use of violence through terror actions. Historically, the arrival and spread of Islam in Southeast Asia is through the peaceful means of trade and education with Sufism emphasis (Ricci 2011). Out of a population of about 650 million, Muslims comprise 40 percent, or around 260 million people, making Islam the most widely embraced religion. Primarily contributed by the large adherents from Malay and Javanese ethnic groups, Southeast Asian Muslims mainly reside in Indonesia, Malaysia, Brunei, the Southern Philippines, and Southern Thailand, all of whom adhere to Sunni denomination with Shafi'i school of Islamic jurisprudence. Before the modern education and formal schooling was widely promoted, Islamic education in ASEAN had typically been institutionalized through pesantren or pondok (Islamic boarding) that have existed since the 14th century (for detailed discussion about this education system in Indonesia, Malaysia, and Thailand, see Hefner and Zaman 2007; Hashim et al. 2011; Liow 2009; Porath 2014). Students gather in a dormitory owned, and guided by, a cleric along with his assistants. Teaching material rests on memorizing the Koran and the classical Islamic books, and is less concerned with modern literature. This educational method is very typical of Southeast Asia, considered effective to teach and disseminate peaceful and tolerant Islamic materials to socioreligious differences in a pluralistic society (Susilo and Syato 2016). Public schools were only introduced by the Dutch in the 19th century. However, until the 1980s, most clerics emphasized to students to only study in boarding schools, making them not interested in attending public schools. Specifically in Indonesia, in 1977 the number of pesantren was only around 4195 with a total of about 677,394 students. Until 2016, the number had rapidly grown to 28,194 with 4,290,626 students (Muhyiddin 2017). All of them are private and have a high degree of independence towards the state. Most Islamic boarding schools are affiliated with the moderate Islamic organization, Nahdlatul Ulama. Until the 1980s, little attention was paid to the relationship between Southeast Asian Islam and extremism. The Soviet-Afghan War (1979-1989) and the Iranian revolution (1978-1979) have been two important factors in the growth of Islamic political activism with the Salafi-Wahhabi character in ASEAN. Many of the former combatants returned home and spread their teachings. Uniquely, 
looking at the effectiveness and appropriateness of Islamic teaching in traditional pesantren and its rooted influence in society, the Wahhabi-Salafi clerics seek to imitate and adopt Islamic boarding school learning models. Some examples are like the Pesantren Al Mukmin Ngruki in Solo, and Al Islam in Lamongan. Very rigid dogmatic teachings have succeeded in indoctrinating students, some of whom were involved in acts of terror either at home or becoming combatants abroad. These pesantrens have a very strong attachment to global terror groups (Van Bruinessen 2004; Wildan 2013). The rise of ISIS and the declaration of the Caliphate in 2014 were addressed with allegiance by several key figures from these institutions (BBC 2016). The rapid development of this group culturally and ideologically has clearly threatened the moderate teaching tradition offered by Islamic institutions that have already existed in Southeast Asia. Because the Salafi-Wahhabi group took a similar institutional model and teaching method in the form of pesantren, in the end these two institutions were opposite vis-à-vis in gaining influence hegemony (Abuza 2003).

Anywhere, an Islamic radical group continually regards groups outside them, especially the West, as enemies to be fought. Similarly, the rapid growth of Salafi-Wahhabi teachings and institutions in Southeast Asia followed by many terror attacks in recent years was such that ASEAN has participated in a vortex of perception as one of the terrorism front bases. Although, this concern is not entirely new as it seems to have started to emerge since the 2002 Bali Bombing, their base in ASEAN further alienated Islam as a religion of peace and honor, since there is almost no Muslim-majority region that is free of terror (Gershman 2002; for more broader perspective on the Western involvement in combating terrorism in Southeast Asia, see also Mauzy and Job 2007). Although, it is noteworthy that today, the Southeast Asian terror groups prefer to target their own nation, law enforcement officials, mainly police and the other groups such as Christians, Shiite, and Ahmadis, compared with their Middle Eastern counterparts focusing against invaders and occupation. This further reinforces that the base and focus of terrorists, and in a more general, of radicals, in ASEAN, is not based on strong social support, and is very vulnerable to external influences. In this context, in essence, Southeast Asian societies generally have a strong historical and cultural experience and narrative for deradicalization: a typical moderate education, which has survived hundreds of years in the region. This paper seeks to explore the drivers of radicalization and social factors that can push an individual to commit to radicalism and terrorism action, explores the various viewpoints of the definition of radicalization as well as its theoretical implications, the characteristics of radicalization in the Muslim world, as well as the analysis of an important part of literacy, the moderate education models of Indonesia in particular and ASEAN in general. Although, unfortunately, moderate education in this region is also facing the threat of radicalization with the emergence of Islamic educational institutions that tend to provide extreme understandings. After analyzing the forms of radical intrusions in Southeast Asia, the last part of the study attempts to describe the specific characteristics and strategical efforts that can be made in the field of education in Indonesia. For three aforementioned parties, i.e., women, children, and the millennial young, the emphasis of this study in examining the capability of moderate education is directed and is expected to be fruitful. By examining diverse views, this study is expected to provide a new horizon in explaining the role and urgency of moderate education as the most effective preventive effort in radicalization. Moreover, the study also explores the important role that millennials can play either as an object of radicalization or through their active participation by presenting capacity they have in combating radicalization.

\section{Focusing the Definition of Radicalization}

There are many meanings of radicalization and there is no satisfactory explanation of the definition precisely. Lentini (2009), in his study of Islamic radicalization, explains that radicalization is an ideological, subcultural, and militant expression in joining in an understanding and interpretation of Islamic theology and jurisprudence, forming social organization and interaction, which encourages one to be an active agent in the global radical transfer of ideology, theology, imagination, and narration. Radicalization is a process of supporting or entering activities that others perceive as threatening 
important social norms. According to this paradigm, the definition of radicalization requires some justification. The first is the degree to which behavioral support for violence reflects a degree of self-engagement in actual violence. Second, it represents a subjective judgment attached by anyone to anyone who violates the perceived norm (Kruglanski et al. 2014). As an implication, the process of radicalization can lead to many directions, including nonviolent resistance. Radicals can enter into nonviolent behavior without intentions that can be perceived as radical (Veldhuis and Staun 2009). For example, it is a rapid radicalization in $d a^{\prime} w a h$ (Islamic propagation) activities or in the earnestness in religious practice. For some, being more diligent in practicing the teachings of religion is a practice that can bring happiness, tranquility, and personal peace. However, for extremists, diligent in worship also means abstaining from the cultural practices and alienation of religious environments that can lead to radical and extreme behavior. Hence, self-alienation to the environment is one of the fundamental reasons for the emergence of radicalization. Moreover, although religious radicalism is often associated with fundamental understanding, in fact fundamentalism is more of an ideological thought than radicalism which requires concrete action. This difference will determine the extent to which a person is willing to be involved in religious violence. Fundamentalism refers to strict adherence to certain doctrines which are considered to be the most original and most ideal. In the context of religion, fundamentalism means the high degree of someone to refer to and use sacred texts to answer a particular problem. Fundamental beliefs basically exist in every adherent of religion along with the function of the sacred text as a basis for one's beliefs. However, the degree of belief in fundamentalist will be higher than that of open-minded individuals in the same religion. (Munson 2006, p. 255) provides more emphasis to fundamentalism which does not only include 'traditional religiosity', but rather a religious response to the ideas of modernity and secularization (see also Marty and Appleby 1991). Because fundamentalism is more solely on the willingness and conviction to only refer to the most sacred text, axiologically, fundamentalists do not necessarily lead to radicalism that promotes the need for revolutionary political reforms and social structures in a comprehensive manner (Zeidan 2018). Supported by fragile social conditions, radicalism advocates change in various social structures of existing values, traditions, and institutions. Radicalists are very likely to use fundamental ideas of a particular ideology for carrying out concrete actions to restore and improve social and political conditions. In addition, although radicalization is driven by backwardness and inferiority, it does not mean that radical actors must have such character. The profile about radical actors in the Muslim world shows that they are frequently not a poor and backward group, but only the combination of religious, fanatical, or desperate characters with social conditions that suppress relative deprivation, such as extreme poverty and political oppression, which have made them radical (CBC Radio 2016; see also Beski-Chafiq et al. 2010). Juergensmeyer (2006) explained that the personal rewards taught in religious doctrines such as heaven and virgins, the existence of supporters and organizational networks based on religious institutions are some of the motivations of individuals or groups to engage in religious violence. It only required external political factors which were deemed deviating from the beliefs of radicalists as a moral justification for actual violence. In many cases, opposition to secularism and the contradiction between God's law and man-made law are some of the most obvious sources of fundamentalism (Juergensmeyer 2002; Munson 2006; Madan 2009).

According to Veldhuis and Staun (2009), radicalism includes every ideological act or expression, including incitement, radical material distribution, recruitment, and persuasion to attain radical views that potentially pose a threat to security either by directing terrorism or by threatening integration and facilitating the spread of radicalization, potentially threatening an ideology (see also Sageman 2004; Christmann 2012). For an expert like Marc Sageman (2008), radicalization is a process of transforming ordinary people into extremists in the sense of violence in the political sphere. The definition from Sageman (2008) necessitates the use of violence as the final goal of politics as a consequence of the process of radical transformation of unexceptional and ordinary beginnings into terrorists. Radicalization involves a change in beliefs, attitude, and behavior in referring to the sectarian violence to justify the expense of defense in the group (McCauley and Moskalenko 
2008). Conflict identification, personal transformation, and willingness to engage in violence are more widely connected with significant social, cultural, and political transformation. Radicalization is a process whereby a person builds, adapts, and disseminates political attitudes, and modes of behavior, which diverges substantially from a value or all values, behaviors, and institutions of political, social, economic, cultural, and religious aspects which have been established or legitimated in one particular society. Radicalization also involves advocacy to change or attempt to alter the status quo through infringement of legitimacy or accept a pursuit-mode political power as elections, civic organizations social protest over the sanctions, and resistance-smooth or nonviolent civil disobedience, and the most threatening one is the use of violence to property or people, either privately owned or state to implement the structure, values, leadership, and the new elite that will usher in a new order of society. Whether their personal use is justifiable to conduct violence or even denying violence entirely, radicalization is advocating significant disruption, displacement, and the most dangerous one is destroying established political, economic, social and social norms and social structures (Lentini 2009).

\section{The Ideological Character of Radicalization in the Muslim World}

There are more than 50 million Muslims living peacefully and enjoying the prosperity of the West. Data from Pew Research Center in The Future of the Global Muslim Population (Pew Research Center 2011) showed that there are about 44 million Muslims in Europe, accounting for 6 percent of the population, and 5 million in the United States. Terror groups do not seem to realize the importance of Islam as the second largest religion in the world, as well as the second largest religion in the West. Although this position should make Muslims have high bargaining power and political, cultural, social, and economic value-added, the bad behavior displayed by this small group will be detrimental to Muslims as a whole, and will be increasingly troublesome to being Muslim, either in the West or the home, in this disrupted age. In the Muslim world, the lack of knowledge about the values of the West and Western attitudes toward Islam has resulted in an extreme attitude and outlook in understanding the effects of Western culture against Muslims. Although, in reality, Muslim extremists reflect a minimal degree of self-identification and are not at all synonymous with Islam substance and the majority of Muslim worldviews, the escalation of anti-terrorism campaigns by Western countries, in addition to the massive terrorist attacks by Muslims in home and Western countries, has led many to believe that Islam is a violent religion that has no place in Western societies and would not be compatible with their cultural, social, and political issues (Roy 2006).

The main goal of religious radicalism is to impose divine law, in public life, and thus replace the worldly rules. The movement of religious radicals began with the idea that the prevailing system is no longer referring to God's law as the only source of legislation. Here, the conception of the existence of deviations from the main sources of divine law, and consequently for the disorder and injustice that exists in society, is strongly attached as the basis of moral justification for making social change through revolutionary action (Juergensmeyer 2015). Specifically in the history of Islam, radicals have existed since the early days of Islam, where the Kharijite adopted anarchism with a very fundamental way of thinking to force the purest divine law and questioned the application of Islam by the Islamic Caliphate at that time (Esposito 1999; Lahoud 2010; Watt 1973). The basic rule is that anyone who does not apply God's law is infidel. Consequently, anyone who is assumed different, does not want to accept, and oppose them will be considered an enemy worth fighting. Although apolitical in the sense that they did not try to establish a rival government, they actively rebelled the government and attacked sporadically other Islamic groups that were considered different from their thoughts. Until now, Muslim radicalists have had the same main goal, even though the methods and nature of application widely vary for each group and region. Some groups, such as the Muslim Brotherhood and its branches, accept party systems and are willing to participate in elections, while other groups such as Al Qaeda and Boko Haram are more inclined to armed violence and reject any symbols of democracy. Hizb ut-tahrir also rejected democracy and actively sought to uphold the Caliphate, but it was more compromising by not adopting violence as a means to an end. Re-establishing the Caliphate, 
as practiced by ISIS, is another way to achieve this goal. Because of differences in these methods, Islamic radical groups are not in one agreement and in some cases, dispute the methods of other groups, and blame and attack each other.

In philosophical discussions, there are at least some characters of radicalism. First, radicalization in Islam is based on resistance to external forces that are perceived as enemies, such as colonialism, liberalism, democracy, globalization, capitalism, multilateral and international agreements, treaties and bodies, even technological advances (De Leede et al. 2017). Second, it is highly affiliated with modern Salafi-Wahhabi puritanism and transnational Islamic organizations. Many researchers argue that almost every contemporary Islamic militant movement is part of, or at least influenced from, the culture of Wahhabism and Salafism (Stemmann 2006; Sagramoso 2012; Wiktorowicz 2001; Tyson 2011). Radical groups in some Southeast Asian countries are also departing from this deadly ideology that is supported by a large financing and operation of a transnational movement system, also functioning as local agents (Abuza 2003; for a discussion about the funding of terrorism in international sphere, see Shapiro and Siegel 2007). The Taliban in Afghanistan and Al Qaeda, for another instance, which has been waging terrorist acts in the world for the last two decades, officially adopted this ideology. There is a strong tendency to resist, to tear down, and to replace established systems of government. This classification is consistent with the definition of terrorism on the assessment of the Council of the European Union as an intentional action conducted for the purpose of intimidation seriously in a group of people, a government, or an international organization to show any action, to destabilize or destroy fundamentals of political, constitutional, economic, or social structures of a country or an international organization (De Leede et al. 2017; see also Cassese 2006). In this sense, the fight against modern social structures and institutions that have been established is the main character of radicalization (Veldhuis and Staun 2009). These radicalization-causing factors form the character of radical movements in the Muslim world. From factors like a combination of poor social conditions, motivational impulses, individual experiences, the radical movement then emerged as an antithetical political establishment that was deemed incapable of bringing satisfaction, but tended to lead to popular dissatisfaction with the ongoing system. By seeing themselves as a representation of the people in the fight against injustice, they exploit the discontent and vacuum of the legitimacy of authority by filling it with radical thinking that seeks to remedy or even eliminate the political, economic, and social status used in a country or region. Although the solutions offered are very simplistic, in fact, radicalization attempts not only to replace authority with new personnel, but also to break them down, such as disbelief of democracy and plurality, which is thought to have caused poverty and moral decline.

Radicalization has a tendency to take forms in religious, political, paramilitary, terrorist, subcultural, counter-cultural, and ideological movements as well as performing acts through violence to take action to achieve goals through violence. In this meaning, there will be an assumption of parent culture as a driving force, which is considered to embody the behavior that is born because of its existence. The parent culture will then give birth to specific subcultures. Subcultures are subdevices or subsets of smaller, more localized, and differentiated structure, in one or more of the wider cultural networks. The subculture should project a fairly distinguishable form and structure to make it easily identifiable from the parent culture. Subcultures should focus on the activity, value, use of material artifacts, certain and distinct spatial spaces that significantly differentiate from broader cultures. However, because the subculture is a subset, it must also be elaborated and articulated significantly from its parent (Waldmann et al. 2009). Put simply, in this context, Islamic radicalization is a movement driven by a politically motivated religious ideology of Islam that carries out action through violence and the realization of a state based on a law dictated by a selective literal interpretation of the Qur'an and Al-Hadith. Islam henceforth is a parent culture, and radicalization is among one of its subcultures. Radicalization reflects a high level of commitment to achieve religious ideological goals. In the most frequent cases, it also does violence as a meaning to achieve that goal. Each subculture is the instant representation of a solution to a set of specific conditions, and the particular contradictive problems. Although there are some relationships, the subculture is not the same as the counter-culture. 
Counter-culture is of nonaffiliated culture being so radically formed from the mainstream assumptions in a society that rarely considers itself part of a culture, but takes its presence as a guide/alarm of foreign intrusion (Cronin 2010). The characteristic of the subculture of Islamic radicalization is at least visible from the literal characters of the scripturalists which are different from the moderate and contextual parent culture of Islam. The fundamental characteristic of radical groups in the literalistic interpretation is evidence of the dominance of the desire to achieve the traditional goals of Islamic beliefs such as the Caliphate (Lentini 2009). These characteristics also coincide with a reduction of commitment to alternative goals and any value understood by them. Conversely, deradicalization as a counter-culture represents a restoration of attention, and reduction of commitment, to achieve ideological goals as the antithesis of radicalization (Kruglanski et al. 2014).

\section{Intrusion of Radical Thought in Moderate Southeast Asian Islamic Education}

The people of Southeast Asia are characterized as inclusive and moderate. Different from its partners the Middle East, in which the minority has no sufficient place in society, Indonesia partially is a home to millions of Christians, Hindus, Buddhists, and other minorities (Kraince 2009). The secular state of Indonesia and the support of the progressive and moderate attitude of Islamic community and organizations have since independence played a vital role in promoting the formation of the nation state and have committed to promoting mutual understanding and respect among faiths since generations (see more detail in Brown 2000). As an implication, education in ASEAN reflects diversity and has played a central role in shaping and transmitting different traditions in the region. Furthermore, these matters have provided a unique character to education of Islamic institutions, that generally put more emphasis on the diversity and mutual understanding. At least until the 20th century, one of the most important characteristics of Islamic Southeast Asia as a whole is its relative absence from Salafi and Wahhabi extremism culture. Furthermore, Islamic education in ASEAN preserves the incredible diversity that is a reflection of the fact that the majority of Muslims throughout the region can find the best relationship with the local culture, ethnicity, and tradition. This tendency, which is called traditionalism in Indonesia, has been enough to move out the spirit and practice of Wahhabi's danger and intolerance (Woodward et al. 2010; Malik 2017).

Particularly, Islamic higher education in Indonesia also plays an important role in restoring interfaith relations as one of the main goals. Passing through the establishment of formal lessons on democracy, citizenship, and initiative of a different curriculum, Islamic universities promote the concept of citizenship that emphasizes the inherent plurality and inclusive society. The rich discourse on Islamic compatibility and democratic pluralism is the main activity in Islamic universities. For instance, unlike conservative Salafist groups, Indonesian modernists in Islamic universities believe in adjusting sharia law in contemporary society (Feener and Cammack 2007). In the view of Muhammadiyah, Islamic law needs to be reformed because in many cases it is no longer contextual for modern conditions. In recent years, there has been a convergence, at least within the scope of the Nahdlatul 'Ulama (NU) and Muhammadiyah elites in religious attitudes and practices. Several NU members studying at Middle Eastern universities have become more resilient to the principle of ijtihad, which is the central discourse for Islamic modernists in Indonesia. Muhammadiyah has also initiated some significant transformations. Although in the past, Muhammadiyah was against Sufi practice, now some Muhammadiyah members practice it (Rabasa 2005; see also Rabasa 2014). Apart from the convergence, some important differences between these two groups persist, especially in their model of political engagement. Muhammadiyah focuses on promoting religious renewal through education and social services, while NU focuses on traditional education in pesantren. This convergence is the two pillars of moderate and progressive Islam in Indonesia in opposing extremism. In addition, the religious system at Malaysia is more affected by traditional practices and beliefs, although in modern times Malaysian is more homogeneous and more orthodox than Indonesian as a result of the centralization of religious authority. Muslims in the Philippines are also heavily influenced by pre-Islamic beliefs and practices. In Indonesia, some pesantren curricula include instruction in secular 
lessons, beyond the main objective of religious teaching based on reading and memorizing the Qur'an (Rabasa 2005). In other parts of ASEAN, the structure and curriculum of private religious education is quite different than that in Indonesia. In Malaysia, for example, the PAS Islamic party has a strong influence in the education and curriculum of Islamic schools. Although the militancy level of the Malaysian Islamic educational system is far from the level of Islamic education militancy as it did in Pakistan, in fact, it also maintains a religious political fundamentalist movement (Othman 2006; for a perspective regarding of this matter in gender spectrum, see for instance in Ghofur and Susilo 2015). In the pesantren cottage in southern Thailand, the national curriculum is taught with additional Islamic subjects. In the past, boarding schools in Thailand helped to maintain the local dialect of Malay and Arabic (Ungpakorn 2003; Bull 2010).

However, the tradition of tolerance in Indonesia and ASEAN was under threat of religious extremists (Kraince 2009). It is worth noting that, apparently, only contemporary radical groups really have a strong political attachment with the struggle, and fundamentalism in the Middle East even attempts to imitate and bring models of social, educational, political, and cultural systems of the Middle East to Indonesia. History proves that the Southeast Asian Muslim struggle is always independent, and scholars and religious leaders have high independence for, for example, propagating religion through religious preaching, culture, or literacy, with local models, although they are often graduates of religious institutions from and descendants from the Middle East. A small number of pesantren in Indonesia teach extremist education and connect with terror organizations. In terms of organization, the style displayed by this institution is extreme in Islamic teaching, which usually based its extremist ideology on the teachings of Ibn Taymiyyah (1263-1328), Muhammad bin Abd al-Wahab (1703-1792), and other Salafi clerics. The thoughts of anti-state political philosophy from Hasan al-Bana (1906-1949), Sayyid Qutb (1906-1966) and other Ikhwanul Muslimin activists emphasizing sharia-based governments, jihad and against all opposing parties to submit under sharia, are also taught in some pesantren. In this context, political change is only one of the broader agendas of the fundamentalist group. In the case of Indonesia, extremists seek to transform Indonesia's Islamic culture with Saudi Arabian culture and religious praxis as its model. Some fundamentalists do not accept the legitimacy of the Indonesian state and think that nationalism and the law outside of shari'a are infidel (Woodward et al. 2010). Islamic extremists in Indonesia are often associated with Arabic clerics; for example, Ja'far Umar Thalib, Abu Bakar Ba'asyir, Abdullah Sungkar, Muhammad Habib Rizieq and others. Some of the moderate characters of Indonesian Islam are in contrast to the characters displayed by the radicalization, often displaying Arabian culture in public as in Arab countries. The differences of perception and actualization by most Indonesians and extremists in interpreting the Islamic teachings have contributed to the growing perceptions among Indonesians who become two interdependent groups. In the discourse of Indonesian society, Wahhabism and terrorism are now becoming clearly connected. Wahhabi terminology is now often associated with fanaticism and violence (Aslam 2012).

The emergence of radicalization is also linked to education in Indonesian universities that have been used as a center for Neo-Wahhabism education by fundamentalist groups with religious and cultural orientation, referring to the Saudi model as a cultural guide and financial support. This culturally and religiously social movement is a complex combination of religious, symbolic, and ideological teaching when viewed from which individuals and communities take and choose different teaching systems and concepts with Indonesian cultural conceptions. However, it is worthwhile that although both are Wahhabi-based groups, the theological teachings presented by radicals are very different from Muhammadiyah. In Indonesia, Wahhabi terminology is used in very different understandings. While such terminology may refer to individuals and organizations that follow the theological teachings of Muhammad ibn Abd al-Wahhab (1703-1792), Muhammadiyah is only purists in understanding by using this terminology in the field of purification confidence of those elements that are considered syncretic to restore the pure Islamic interpretation and not receptive to heterodox beliefs and cultural traditions, and it is very active in promoting societal reformation, economic development, and educational modernization with more reference to the theology and idealism of Jamal Al-Din 
Al-Afghani (1838-1897), Muhammad Abduh (1849-1905), and Muhammad Rashid Ridha (1865-1935) (Woodward et al. 2010; see also for the influence of Muslim reformers on the Muhammadiyah in Shabir and Susilo 2018). In some cases, Islamic boarding schools in Thailand are used as a means of recruiting militants and separatist campaigns. In the Philippines, Islamic schools with a formal education system are generally moderate in character, and only a few of the radical characteristics are usually funded by Saudi Arabia. In Indonesia and Malaysia, a small number of radical Islamic schools serve as an incubator of radical movements, including regional terrorist organizations Jemaah Islamiyah and its political frontier, Majlis Mujahidin Indonesia (MMI). Other schools in Yala, Thailand, have a special relationship and are influenced by Wahhabi. In addition to their very small numbers, which indicates the low acceptance of Indonesian Muslim societies over the methods taught in radical institutions, radical pesantren show the disproportion of teachings that have been capable of influencing the radical formation and propagation (Rabasa 2005).

\section{Urgency of Contextualization of Deradicalization Based on Local Education}

Much effort has been made in deradicalization, and includes recent efforts through rehabilitation, with humanist, communicative, and participatory emphasis deemed unsuccessful. These efforts have at least less-developed a paradigm of emphasis on three unified aspects of education, moderatism, and localization. It is worthwhile to note that radicalization is also related to the context of social, political, and economic conditions in an area combined with the degree of individual autonomy in seeking identity, and thus the deradicalization necessitates consideration of sociopolitical and geographical culture as its basis. This is based on the reason that Islamic radicalization, despite its transnational character, contains local elements that make radicalization possible in one region and not appear in the other. Contextualizing deradicalization is based on the view that the basic teachings of Islam are constant, but its application is not monolithic. Islamic applications will be changed and moved across geographical borders and entry into new areas and varies with different fundamental difference. This variation is often the result of political influence, cultural, economic, and social issues in an environment where Islam is practiced. Furthermore, the degree of autonomy of an individual in control of the political system to exercise freedom of expression affects religious beliefs and practices. Character displayed by the understanding of the radical actors would be appropriate in certain contexts. Among Muslims, there are two different movements in addressing reform and modernity. The first group approved a pluralistic democracy that is based on tolerance, social justice, and civil society. The second group promotes Islam as a political ideology that aims to control the country on sectarian basis, a phenomenon that refers to Islamism. With the emphasis on moral reform, advocating Islamization of Indonesian society as a whole is through imposition of Islamic law on the basis of a large Muslim population, as well as by changing established social norms with typical Wahhabism teachings (Kraince 2009). Thus, in the case of Indonesia, the effective deradicalization should consider the characteristics of the culture and local sociopolitical conditions. Radicalization in Indonesia is a strange phenomenon, though still possible, because of inexistence of deprivative conditions that can bring radicalization. Relative deprivation refers to inequality of social structures in a broad sense, such as poverty, lack of access to education, unemployment, and poor housing. In many cases, relative deprivation is the fundamental cause of radicalization (Hegghammer 2006). Among the success of Indonesian Islam in the contemporary period is a positive recognition from international community as a most tolerant and democratic Muslim-majority country (Ramage 1997; for a detailed assessment of the compatibility of democracy with and modern Muslim society, see Voll 2007; Tibi 2009; Stepan and Robertson 2003). They also tend to be syncretic in terms of acceptance of cultural and religious minorities. Indonesian Muslims also tend to absorb the previous culture influenced by Buddhist, Hindu, and customary practices. Although the ultra-orthodox groups in Indonesia are very small, they have to take a stance on the authority of the secular opposition and threaten democratic values and the plurality by spreading and increasing militancy (Coulson 2004). 
Hence, some characters of radicalization can be starting points of deradicalization. The most noticeable is that radicalization can form in the understanding or action that begins on the transformation of radical ideas in education. In this context, the role of education is very relevant and urgent given that education and radicalization have a meeting point in the transformation of knowledge and understanding. Education has a role in the transformation of radicalization in the early stages and is a key element in forming the fundamental ideas of radicalization. On the other hand, moderate and inclusive education has also become the most considerable factor in deradicalization (LaRue 2012). Because radicalization can be merely an extreme form of understanding, then the transformation process of radicalization may not be associated with violence. Violent radicalization may be included in the process of adoption of the belief system that promotes violence, but this does not imply that the radical also would act violently. In many cases, people who were radicalized refrain from entering terrorist activity. Action on terror, as one of the worst possibilities and indisputable, is the result of understanding of violent radicalization. In other words, every terrorist is a radical, but not necessarily a radical terrorist. Moreover, education has a role as well as responsibility associated with the growing of both radicalization and deradicalization. Islamic educational institutions are sometimes used by radical groups to spread the ideas and beliefs of extremists to justify the verses of the Qur'an and other religious texts (Coulson 2004; Tighe 2011; Middleton 1987). Empirically, the importance of educational institutions in the deradicalization program is at least visible from a massive re-education of the radical ideas in some Muslim countries (Cronin 2010). The reduction of exclusivism and alienation as well as counter-discrimination in education is one of the reasons for teaching children as early as possible about the different cultures and religions to live harmoniously, build inclusive, tolerant, and respectful attitudes in facing the diversity. Youth, or millennial as the most important object in education, can sometimes be the target of terrorists because of their infancy and in a period of education and the search for personal identity included as a stage of the radicalization process (for an insightful and comprehensive analysis related to this can be seen in Hope and Matthews 2018; see also Liang 2015). They can or cannot find radical ideas based on the extent to which the education can provide sufficient understanding regarding tolerance and were looking for a personal identity. Because education is such a dominant role in the elimination of radicalization in the prevention stage, so many counter-terrorism policies target young people. For example, US policy in Africa is based on the reason for shortage of persistent education, provision of housing, and the opportunity of vocational education as well as the demands of marginalized populations. A similar policy is also executed in the Islamic countries in Africa such as Chad, Niger, Mauritania, Mali, Senegal, Nigeria, Morocco, Tunisia, and Algeria as the main locations of the extremism (Aldrich 2014). Hence, teaching tolerance and respect for different religions and traditions has helped to reduce the experience of alienation. Many analysts agree that the alienation or discriminatory treatment is one of the fundamental causes of radicalization. Alienation becomes very obvious in analyzing the behavior of radicals that occur in the Western world, especially that conducted by Muslim actors with the example such as discrimination in immigration, Islamophobia, and rejection of the Islamic religion in general (see Maira 2011). It also may have positive implications in counterterrorism activities. The US Counterterrorism Commission, which makes the purpose of education as a means to counteract radicalization, mentions that teaching tolerance, sovereignty, and individual value, respect for the different beliefs, are key elements in the global strategy to eliminate radical ideas (Webber 2011).

\section{Triple Helix in Deradicalization: Localization, Moderate and Education}

For contextualizing, it is needed to elaborate some characteristics of Southeast Asian Islamic moderate education that need to be emphasized in radicalization. Historically, the development of Islam in Southeast Asia is considered to be spread by foreigners like Indian, Persian, or Arabs (Tarling 1992; Reid 1988). Afterwards, they established a typical pesantren with local content in Islamic education (Azra et al. 2007; Lukens-Bull 2006). Pesantren is very massive in teaching Islam, especially in the younger generation, and in certain times teaching taught to the outside community, many of 
which targeted parents, including mothers (Dhofier 1980). On the other hand, the spread of radical viruses is not directly derived from these typical local Islamic teachings, and specifically, none of these traditional pesantren taught radicalization, in the absence of stakeholder involvement in this action. Thus, the inclusion and emphasis of further deradicalization actions on pesantren should take precedence. Second, the involvement of moderate organizations in radicalization by involving, in particular Indonesia, the two largest Islamic moderate organizations, Nahdlatul Ulama and the Muhammadiyah, that have members up to tens of millions of people. Their active involvement, of course, will be more effective in preventive efforts through education, in terms of the number of educational institutions held at all levels and models. Because the cutting-edge focus of radical groups in Southeast Asia not only stays in one place, but seeks to make this region as a whole as a forthcoming base, it makes the region generally vulnerable to attack (Acharya and Acharya 2007). Therefore, the dissemination and teaching efforts of pesantren and such teaching conducted by moderate organizations should be disseminated throughout the region, including with other countries, and with other religious educational institutions, including Buddhism, Hinduism, and Christianity as the other three major religions in the region. At the very least, this effort can serve as a basis for mutual cooperation, and mutual understanding among civil society and organizations in the fight against radicalization and its consequences.

Furthermore, even though debatable, the war effort with radically charged texts should be strengthened. The argument that this action is contrary to the principle of freedom of expression has, at least, been considered a failure in some countries, with strict censorship, blocking, and banning of radically charged material in cyberspace. This effort should not just stop, and be passed on to the virtual world, but also on to books, and printed publications. This is because radicals do not originate from a temporary understanding, but also cognitively initiated through the existence of radical teaching, which is processed continuously through readings and other cognitive aspects. Some recent evidence proves that radically charged material always accompanies in every act of terror. Furthermore, young groups and children deserve protection in every level of education from radical teachings, by strengthening the role of educational institutions in extracurricular activities. The evidence also shows that intracollege organizations are one source of the development of radical teachings, which have increasingly shown the involvement and approval of radical action since youth. These targets have long been an important subject by radical groups, and at the same time they are aware of the antithesis of triple helix of local-moderate-education, and move it on to global-extremism-education, as material taught to young groups. This further reinforces that in fact, local phenomena, in the context of ASEAN cannot be too successful in spreading radicalization. If terror occurs, the perpetrators have long admitted that there is injustice to Muslims at the global level, and that extremist organizations have long struggled against it. The narrative of enemies at this global level makes them very vulnerable to falling into radicalization. Then, localization becomes another very important aspect of deradicalization. With these various characteristics and strategies, it is hoped that the contextualization of deradicalization through moderate local Islamic education can show its urgency. Furthermore, with these all, these three elements can effectively become a unity in deradicalization, particularly in ASEAN, and will be able to serve as a theoretical and practical review as a parent culture in the deradicalization.

\section{Conclusions}

Radicalization in the form of aggressive and revolutionary occurred after the process of radicalization has the physical strength and weapons. However, before reaching the process, experts agree that radicalization is a gradual process, although it happens very quickly, which specifically does not have a prefix or suffix. For individuals, radicalization process is initiated by a combination of various factors of personal experience, culture, and social environment that makes people undergo a process of drastic changes in attitudes and behavior. As radicalization involves active understanding and thought, in this case, the role of education that serves as a transforming knowledge to prevent radical understanding is very relevant. Radicalization's greatest concern, especially in a political 
context, is terrorism and global enemies that have been used as a justification to fight political entity or social existing. Moreover, localizing the narratives of education is required, given that although the basic teachings of Islam are constant, the application by its adherents throughout the world is not monolithic. Islamic applications will be changed and moved across geographical borders and entry into new areas and varies with different fundamental difference. An important example of radicalization in Indonesia in particular is their imitation of pesantren-based learning models. This reflects radicalist adoption of local values which are considered more enabling to disseminate the influence of their teachings on students and society.

To that end, to offer another practical strategy, an overall strategy to deconstruct the idea of Wahhabi radicalization in Indonesia should be implemented in several ways. First, the record needs to be set straight between Indonesian Muslim education in general and in schools and college in particular. Indonesian Islamic educational institutions, with few exceptions, did not support and promote extremism with their ideological orientation that tends toward syncretic character in the field of jurisprudence and Sufism. Traditional institutions of Indonesian Islam are the historical evidence capable of providing antagonistic reduction on the principles and actions of extreme Wahhabi. Reducing extremist teachings of Wahhabism is very possible, regarding that the relationship between Wahhabis and extremism is a correlational relationship, and not just causality. Sociohistorically, the deconstruction of the Wahhabi ideas is very possible given that the majority of the Muslim community in Indonesia and other countries that follow the Wahhabi doctrine do not perform the same action with the Wahhabi terrorism and reject all forms of violence as a basis of ideological-religious justification; basically, Neo-Wahhabism that has developed along with the radical understanding and Arabization programs become an irrational and ahistorical context of Indonesia. This is because, historically, Indonesia has experienced a period of renewal of Islam brought by the modernists in the organization of Muhammadiyah, which in turn can come together and play an active role in the context of cultural, political, educational, economic, and social elements in Indonesian modern state.

Author Contributions: S.S. conceptualized the study and wrote the major parts of the paper, including methodology, formal analysis, and literature review, as well as the interpretation of results. R.P.D. contributed to the interpretation of results, supervision and final approval.

Funding: This research received no external funding.

Acknowledgments: The initial draft of this manuscript was presented at the International Conference on Islamic and Muslim Societies (ICONIS) 2018, "Being Muslim in a disrupted millennial age", August 1 to 2, 2018, hosted by the Salatiga State Islamic Institute at Laras Asri Resort and Spa, Salatiga, Central Java. The authors would like to thank the steering committee, Zakiyuddin Baidhawy and Noor Malihah for allowing the author to present the work. The authors are grateful to the anonymous reviewers for constructive suggestions. We thank Pablo Velazquez for sincerely helping us in the publication process. This work is dedicated for Desi Setya Ngaeni and Izzakhild Ailani Sulistyo for all of the love and support.

Conflicts of Interest: The authors declare no conflict of interest.

\section{References}

Abuza, Zachary. 2003. Funding terrorism in Southeast Asia: The financial network of Al Qaeda and Jemaah Islamiya. Contemporary Southeast Asia 25: 169-99. [CrossRef]

Acharya, Amitav, and Arabinda Acharya. 2007. The Myth of the second front: Localizing the 'war on terror' in southeast Asia. Washington Quarterly 30: 75-90. [CrossRef]

Aldrich, Daniel. 2014. First Steps Towards Hearts and Minds? USAID's countering Violent Extremism Policies in Africa. Terrorism and Political Violence 26: 523-46. [CrossRef]

Aslam, Maleeha. 2012. Gender-Based Explosions: The Nexus between Muslim Masculinities, Jihadist Islamism and Terrorism. New York: United Nations University Press.

Azra, Azyumardi, Dina Afrianty, and Robert Hefner. 2007. Pesantren and madrasa: Muslim schools and national ideals in Indonesia. In Schooling Islam: The Culture and Politics of Modern Muslim Education. Edited by Robert W. Hefner and Muhammad Qasim Zaman. Princeton: Princeton University Press, pp. 172-98. 
BBC. 2016. The Islamic State Group's Influence in Indonesia. Available online: https://www.bbc.com/news/ world-asia-35312624 (accessed on 30 December 2018).

Berger, J. M. 2014. The Islamic State vs. al-Qaeda: Who's Winning the War to Become the Jihadi Superpower? Available online: http:/ / foreignpolicy.com/2014/09/02/the-islamic-state-vs-al-qaeda/ (accessed on 30 December 2018).

Beski-Chafiq, Chahla, Jane Birmant, Hichem Benmerzoug, Akim Taibi, and Ariane Goignard. 2010. Youth and Islamist Radicalisation Lille, France. Aarhus: Center for Studies in Islamism and Radicalization (CIR) Aarhus University.

Brown, Carl. 2000. Religion and State: The Muslim Approach to Politics. New York: Columbia University Press.

Bull, Ronald L. 2010. Madrasa by Other Name Pondok, Pesantren, and Islamic School in Indonesia and Larger Southeast Asian Region. Journal of Indonesian Islam 4: 1-21. [CrossRef]

Cassese, Antonio. 2006. The multifaceted criminal notion of terrorism in international law. Journal of International Criminal Justice 4: 933-58. [CrossRef]

CBC Radio. 2016. The Surprising Profile of an Islamic Radical. Ottawa: CBC Radio, Available online: http:/ / www. cbc.ca/radio/tapestry/debunk-1.3826142/the-surprising-profile-of-an-islamic-radical-1.3826190 (accessed on 30 December 2018).

Christmann, Kris. 2012. Process Evaluation of Preventing Violent Extremism Programs for Young People. Wales: Youth Justice Board Report.

Coulson, Andrew. 2004. Education and indoctrination in the Muslim world. Policy Analysis 29: 1-36.

Cronin, Audrey. 2010. The evolution of counterterrorism: will tactics trump strategy? International Affairs 86: 837-56. [CrossRef]

De Leede, Seran, Renate Haupfleisch, Katja Korolkova, and Monika Natter. 2017. Radicalisation and Violent Extremism-Focus on Women: How Women Become Radicalised, and How to Empower Them to Prevent Radicalisation. Commitee on Women's Rights and Gender Equality, Policy Department on Citizens' Rights and Constitutional Affairs, Directorate General for Internal Policies of the Union. Available online: http:/ / www.europarl.europa.eu/RegData/etudes/STUD/2017/596838/IPOL_STU(2017)596838_EN.pdf (accessed on 30 December 2018).

Dhofier, Zamakhsyari. 1980. The Pesantren Tradition: A Study of the Role of the Kyai in the Maintenance of the Traditional Ideology of Islam in Java. Ph.D. dissertation, Australian National University, Canberra, Australia.

Esposito, John. 1999. The Oxford History of Islam. Oxford: Oxford University Press.

Feener, Michael, and Mark Cammack. 2007. Islamic Law in Contemporary Indonesia: Ideas and Institutions. Cambridge: Islamic Legal Studies Program Harvard University, Volume 5.

Gershman, John. 2002. Is Southeast Asia the second front? Foreign Affairs 81: 60-74. [CrossRef]

Ghofur, Abdul, and Sulistiyono Susilo. 2015. Perempuan dan Narasi Kekerasan: Studi Kritis Peran Gender dalam Deradikalisasi. Teosofi: Jurnal Tasawuf dan Pemikiran Islam 5: 431-54. [CrossRef]

Hadler, Jeffrey. 2008. Muslims and Matriarchs: Cultural Resilience in Indonesia through Jihad and Colonialism. Ithaca: Cornell University Press.

Hashim, Rosnani, Saheed Ahmad Rufai, and Mohd Roslan Mohd Nor. 2011. Traditional Islamic education in Asia and Africa: A comparative study of Malaysia's Pondok, Indonesia's Pesantren and Nigeria's traditional Madrasah. World Journal of Islamic History and Civilization 1: 94-107.

Hefner, Robert, and Muhammad Qasim Zaman. 2007. Schooling Islam: The Culture and Politics of Modern Muslim Education. Princeton: Princeton University Press, Volume 37.

Hegghammer, Thomas. 2006. Terrorist recruitment and radicalization in Saudi Arabia. Middle East Policy 13: 39-60. [CrossRef]

Hope, Andrew, and Julie Matthews. 2018. How Not to Be a Terrorist': Radicalisation and Young Western Muslims' Digital Discourses. In Young People Re-Generating Politics in Times of Crises. Edited by Sarah Pickard and Judith Bessant. Basingstoke: Palgrave Macmillan, pp. 161-77.

Juergensmeyer, Mark. 2002. Religious terror and global war. In Understanding September 11. Edited by Craig Calhoun, Paul Price and Ashley Timmer. New York: New Press.

Juergensmeyer, Mark. 2006. From Bhindranwale to Bin Laden: A search for understanding religious violence. In Religion and Conflict in South and Southeast Asia. Edited by Linell Cady and Sheldon Simon. London: Routledge, pp. 31-40. 
Juergensmeyer, Mark. 2015. Entering the Mindset of Violent Religious Activists. Religions 6: 852-59. [CrossRef] Kadir bin Che Man, Wan. 1987. Muslim Separatism: The Moros of Southern Philippines and the Malays of Southern Thailand. Ph.D. dissertation, Australian National University, Canberra, Australia.

Kraince, Richard. 2009. The Challenge to Religious Liberty in Indonesia. Backgrounder 2279: 1-14.

Kruglanski, Arie, Michele Gelfand, Jocelyn Bélanger, Anna Sheveland, Malkanthi Hetiarachchi, and Rohan Gunaratna. 2014. The psychology of radicalization and deradicalization: How significance quest impacts violent extremism. Political Psychology 35: 69-93. [CrossRef]

Lahoud, Nelly. 2010. The Jihadis' Path to Self-Destruction. London: Hurst \& Co.

LaRue, Frederick. 2012. Birthplace or Meeting Place? An Analysis of Student Muslim Radicalization in American Universities. Master thesis, Lehigh University, Bethlehem, PA, USA.

Lentini, Pete. 2009. The transference of neojihadism: Towards a process theory of transnational radicalisation. In Proceedings from the GTReC International Conference, Radicalisation Crossing Borders: New Directions in Islamist and Jihadist Political, Intellectual, and Theological Thought in Practice. Melbourne: Global Terrorism Research Centre, Monash University.

Liang, Christina. 2015. Cyber Jihad: understanding and countering Islamic State propaganda. GSCP Policy Paper 2: 1-12.

Liow, Chinyong. 2009. Piety and Politics: Islamism in Contemporary Malaysia. New York: Oxford University Press.

Lukens-Bull, Ronald. 2006. Pesantren education and religious harmony: Background, visits, and impressions. In Religious Harmony: Problems, Practice, and Education, Paper presented at Regional Conference of the International Association for the History of Religions, Yogyakarta and Semarang, Indonesia, September 27-October 3. Edited by Michael Pye, Edith Franke, Alef Theria Wasim and Abdurrahman Mas' ud. Berlin: Walter de Gruyter, vol. 45, pp. 315-21.

Madan, Triloki Nath. 2009. Modern Myths, Locked Minds: Secularism and Fundamentalism in India. Oxford: Oxford University Press.

Maira, Sunaina. 2011. Islamophobia and the War on Terror: Youth, citizenship, and dissent. In Islamophobia: The Challenge of Pluralism in the 21st Century. Edited by John Esposito and Ibrahim Kalin. Oxford: Oxford University Press.

Malik, Maszlee. 2017. Salafism in Malaysia: Historical Account on Its Emergence and Motivations. Sociology of Islam 5: 303-33. [CrossRef]

Marty, Martin, and Scott Appleby. 1991. Fundamentalism Observed. Chicago: University of Chicago Press, vol. 1.

Mauzy, Diane, and Brian Job. 2007. US policy in Southeast Asia: Limited re-engagement after years of benign neglect. Asian Survey 47: 622-41. [CrossRef]

McCauley, Clark, and Sophia Moskalenko. 2008. Mechanisms of political radicalization: Pathways toward terrorism. Terrorism and Political Violence 20: 415-33. [CrossRef]

Middleton, Sue. 1987. Schooling and Radicalization: Life Histories of New Zealand feminist teachers. British Journal of Sociology of Education 8: 169-89. [CrossRef]

Muhyiddin. 2017. Pertumbuhan Pesantren di Indonesia Dinilai Menakjubkan (The Growth of Islamic Boarding Schools in Indonesia is Considered Amazing). Available online: https: / / www.republika.co.id/berita/dunia-islam/islam-nusantara/17/11/30/p088lk396-pertumbuhanpesantren-di-indonesia-dinilai-menakjubkan (accessed on 30 December 2018).

Munson, Henry. 2006. Fundamentalism. In The Blackwell Companion to the Study of Religion. Edited by Robert A. Segal. Malden: Blackwell Publishing, pp. 255-69.

Niemi, Pia-Maria, Saija Benjamin, Arniika Kuusisto, and Liam Gearon. 2018. How and Why Education Counters Ideological Extremism in Finland. Religions 9: 420. [CrossRef]

Othman, Norani. 2006. Muslim women and the challenge of Islamic Fundamentalism/extremism: An overview of Southeast Asian Muslim women's struggle for human rights and gender equality. Women's Studies International Forum 29: 339-53. [CrossRef]

Pew Research Center. 2011. The Future of the Global Muslim Population. Washington: Pew Research Center, Available online: http:/ / www.pewforum.org/2011/01/27/the-future-of-the-global-muslim-population/ (accessed on 30 December 2018).

Porath, Nathan. 2014. Muslim Schools (Pondok) in the South of Thailand: Balancing Piety on a Tightrope of National Civility, Prejudice and Violence. South East Asia Research 22: 303-19. [CrossRef]

Rabasa, Angel. 2005. Islamic Education in Southeast Asia. Current Trends in Islamist Ideology 2: 97-108. 
Rabasa, Angel. 2014. Political Islam in Southeast Asia: Moderates, Radical and Terrorists. London: Routledge.

Ramage, Douglas. 1997. Politics in Indonesia: Democracy, Islam and the Ideology of Tolerance. Hove: Psychology Press.

Reid, Anthony. 1988. Southeast Asia in the Age of Commerce, 1450-1680: Expansion and Crisis. New Haven: Yale University Press, vol. 2.

Ricci, Ronit. 2011. Islam Translated: Literature, Conversion, and the Arabic Cosmopolis of South and Southeast Asia. Chicago: University of Chicago Press.

Rokhmad, Abu, and Sulistiyono Susilo. 2017. Conceptualizing Authority of the Legalization of Indonesian Women's Rights in Islamic Family Law. Journal of Indonesian Islam 11: 489. [CrossRef]

Roy, Olivier. 1996. The Failure of Political Islam. Cambridge: Harvard University Press.

Roy, Olivier. 2006. Globalized Islam: The Search for a New Ummah. New York: Columbia University Press.

Roy, Olivier. 2007. Secularism Confronts Islam. New York: Columbia University Press.

Roy, Olivier. 2008. Al Qaeda in the West as a youth movement: The power of a narrative. CEPS Policy Brief 168: 1-8. [CrossRef]

Sageman, Marc. 2004. Understanding Terror Networks. Philadelphia: University of Pennsylvania Press.

Sageman, Marc. 2008. A strategy for fighting international Islamist terrorists. The Annals of the American Academy of Political and Social Science 618: 223-31. [CrossRef]

Sagramoso, Domitilla. 2012. The Radicalization of Islamic Salafi Jamaats in the North Caucasus: Moving Closer to the Global Jihadist Movement? Europe-Asia Studies 64: 561-95. [CrossRef]

Shabir, Muslich, and Sulistiyono Susilo. 2018. Muhammad Abduh's Thought on Muhammadiyah Educational Modernism: Tracing the Influence in Its Early Development. Qudus International Journal of Islamic Studies 6: 127-60. [CrossRef]

Shapiro, Jacob, and David Siegel. 2007. Underfunding in terrorist organizations. International Studies Quarterly 51: 405-29. [CrossRef]

Stemmann, Juan. 2006. Middle East Salafism's influence and the radicalization of Muslim communities in Europe. Middle East Review of International Affairs 10: 1-16.

Stepan, Alfred, and Graeme B. Robertson. 2003. An "Arab" more than a "Muslim" democracy gap. Journal of Democracy 14: 30-44. [CrossRef]

Susilo, Sulistiyono, and Ibnu Syato. 2016. Common identity framework of cultural knowledge and practices of Javanese Islam. Indonesian Journal of Islam and Muslim Societies 6: 161-84. [CrossRef]

Tagliacozzo, Eric. 2009. Southeast Asia and the Middle East: Islam, Movement and the Longue Durée. Stanford: Stanford University Press.

Tan, Andrew. 2000. Armed Muslim separatist rebellion in Southeast Asia: Persistence, prospects, and implications. Studies in Conflict and Terrorism 23: 267-88. [CrossRef]

Tarling, Nicholas. 1992. The Cambridge History of Southeast Asia: from Early Times to C. 1800. Cambridge: Cambridge University Press, vol. 1.

Tibi, Bassam. 2009. Islamism and democracy: On the compatibility of institutional Islamism and the political culture of democracy. Totalitarian Movements and Political Religions 10: 135-64. [CrossRef]

Tighe, Evan. 2011. Trust in Allah, But Tie Your Camel: The Effects of Radicalized Schooling and State Security on Islamic Terrorism in the Middle East. Ph.D. dissertation, University of Georgia, Athens, GA, USA.

Tyson, Adam. 2011. De-Radicalization in Indonesia: Discourses and strategies. SEARCCT's Selection of Articles 2: 27-38.

Ungpakorn, Ji. 2003. Radicalising Thailand: New Political Perspectives. Bangkok: Institute of Asian Studies Chulalongkorn University.

Van Bruinessen, Martin. 2004. Traditionalist' and 'Islamist' pesantrens in Indonesia. Paper presented at the Workshop 'The Madrasa in Asia, Transnational Linkages and Alleged or Real Political Activities', Leiden, The Netherlands, May 24-25.

Vaughn, Bruce, Emma Chanlett-Avery, Richard Cronin, Mark Manyin, and Larry Niksch. 2005. Terrorism in Southeast Asia. Washington: Library of Congress Washington DC Congressional Research Service.

Veldhuis, Tinka, and Jørgen Staun. 2009. Islamist Radicalisation: A Root Cause Model. The Hague: Netherlands Institute of International Relations Clingendael.

Voll, John. 2007. Islam and democracy: Modernization is a barrier? Religion Compass 1: 170-78. [CrossRef] 
Waldmann, Peter, Matenia Sirseloudi, and Stefan Malthaner. 2009. Where does the radicalisation process lead? Radical community, radical networks and radical subcultures. In Understanding Violent Radicalisation: Terrorist and Jihadist Movements in Europe. Edited by Magnus Ranstorp. London: Routledge, pp. 50-67.

Watt, William Montgomery. 1973. The Formative Period of Islamic Thought. Edinburgh: Edinburgh University Press. Webber, Diane. 2011. Education as a Counterterrorism Tool and the Curious Case of the Texas Book Resolution. University of Maryland Law Journal of Race, Religion, Gender E Class 11: 271-92.

Wiktorowicz, Quintan. 2001. The New Global Threat: Transnational Salafi and Jihad. Middle East Policy 8: 18-38. [CrossRef]

Wildan, Muhammad. 2013. Mapping radical Islam: A study of the proliferation of radical Islam in Solo, Central Java. In Contemporary Developments in Indonesian Islam: Explaining the "Conservative Turn. Edited by Van Bruinessen. Singapore: Institute of Southeast Asian Studies, pp. 190-223.

Woodward, Mark, Inayah Rohmaniyah, Ali Amin, and Diana Coleman. 2010. Muslim education, celebrating Islam and having fun as counter-radicalization strategies in Indonesia. Perspectives on Terrorism 4: 28-50.

Zeidan, David. 2018. The Resurgence of Religion: A Comparative Study of Selected Themes in Christian and Islamic Fundamentalist Discourses. Leiden: Brill.

(C) 2019 by the authors. Licensee MDPI, Basel, Switzerland. This article is an open access article distributed under the terms and conditions of the Creative Commons Attribution (CC BY) license (http:/ / creativecommons.org/licenses/by/4.0/). 